\title{
Perception of Stakeholders towards the Effectiveness of Diploma Programs: A Case Study of Saudi Arabian University
}

\author{
Khalid Abdullah Alotaibi ${ }^{1, *}$ \\ ${ }^{1}$ College of Education, Salman Bin Abdulaziz University, Al-Kharj, Saudi Arabia \\ *Correspondence: College of Education, Salman Bin Abdulaziz University, Al-Kharj, Saudi Arabia. E-mail: \\ ka.alotaibi@sau.edu.sa
}

Received: April 23, 2014

Accepted: June 11, $2014 \quad$ Online Published: August 12, 2014

doi:10.5430/wje.v4n4p81

URL: http://dx.doi.org/10.5430/wje.v4n4p81

\begin{abstract}
The success of civilization is determined by the excellent education system and excellent education program. It is believed that the aims of producing outstanding and dedicated students are determined by the quality of education program. Students chose the education program based on many criteria, like job guarantee, reputation of the university, duration of the program etc. For the present research perception of stakeholders towards the effectiveness of diploma program, Majmaah University was selected. Questionnaire was distributed among the stakeholders of diploma program which include teachers, faculty members, members of the university's chancellery, employers, funding body etc. To find out their perception towards the effectiveness of diploma program, different statistical tools were used to complete the present research. In the findings it has been found that there is a positive perception of stakeholders towards the effectiveness of diploma program.
\end{abstract}

Keywords: stakeholders; Majmaah University; diploma programs

\section{Introduction}

To find the perception of stakeholders towards the effectiveness of diploma program, there are many universities in Saudi Arabia. For this research Majmaah University is chosen. It is considered one of the most recent universities in Saudi Arabia. This university and the universities like this were established to provide students of different regions with different academic skills, satisfy their scientific aspirations and to increase their awareness of their academic responsibilities, and encourage them to exert more efforts in solving the academic and personal problems that hinder their abilities from achieving optimum educational goal. Students are also initiated and encouraged to interact with the socio-cultural demands of the university life.

In the same context of encouraging the establishment of new universities there has been an expansion in the provision of specialized diploma programs in the Saudi universities in general and the Majmaah university in particular. This comes as a continuation for the performance of the University mission to serve the people of Saudi society, who wish to achieve their ambitions and to continue their studies, the university carries out educational programs (Adult Education) in the province of Hafr Albatin, in cooperation between the Deanship of Community Service and Continuing Education and the Institute of Prince Salman for Studies and Advisory Services in the University. These programs are: Diploma in General Education (high), a Diploma in Guidance and Counseling Students (high), Diploma in Learning Resource Centers (high), Special Education Diploma, a diploma of Measurement and Evaluation (high), Attorneys' Diploma, Bachelor of Accounting and a Diploma of Technology Networks. The Majmaah University also launched the training program for the health diploma holders at the university in 2013, Computer Science Diploma (Networks Technology) in 2011. In addition, the university conducts seven educational programs (education parallel) in the city of Riyadh via the Deanship of Community Service and Continuing Education and the Institute of Prince Salman for studies and advisory services in 2012 (Majmaah, 2012)

\subsection{Terms of the Study: Evaluation}

The evaluation is considered one of an important part of effective teaching. As the title suggests the recent study is a measurement and evaluation of the effectiveness of diploma-level training in eight different academic fields in 
Majmaah University. To begin, it is important to shed light on the major terms of the study. It is remarkable that evaluation is not equivalent to research, although it employs research techniques as a means of generating the necessary information, and uses similar criteria for the reliability and validity to judge the quality of the evidence. Also, evaluation tends to be broader than research, as it usually requires information about a range of situations, products and processes. However, the main difference between evaluation and research is that evaluation involves making judgments about the value of what is being evaluated (Manchester, 2013).

However, evaluation can be formalised to an extent that it becomes research. Indeed, the focus of this project, where we are seeking explicit evaluation plans, is close to research. The problem with the label 'research' is that a great deal of evaluation research is flawed. Reeves (1993) list several of these flaws:

- vague specification of primary independent variables;

- lack of linkage to robust theory;

- small sample size;

- inadequate literature review;

- inadequate treatment time (conclusions are sometimes made after students use materials for minutes);

- obscure statistical analysis;

- measurement flaws (precise measurement of easy-to-measure variables; more complex variables, which might be the crucial ones, are ignored);

- inconsequential outcome measures (Philips, 2000)

There are two common purposes in educational evaluation which are, at times, in conflict with one another. Educational institutions usually require evaluation data to demonstrate effectiveness to funders and other stakeholders, and to provide a measure of performance for marketing purposes. Educational evaluation is also a professional activity that individual educators need to undertake if they intend to continuously review and enhance the learning they are endeavoring to facilitate (World News, 2012). There are three main Standards for educational evaluation we should bear in mind when conducting the process of evaluation. The Joint Committee on Standards for Educational Evaluation (An American/Canadian based Standards Developer Organization (SDO) that represents a coalition of major professional associations formed in 1975 to help improve the quality of standardized evaluation) published three sets of standards for educational evaluations. The Personnel Evaluation Standards was published in 1988, The Program Evaluation Standards (2nd edition) was published in 1994, and The Student Evaluations Standards was published in 2003.

\section{Review of Literature}

There is a good number of researches which favors the continuous use of professional development activities to improve academic programs on both levels of schools and universities. However, there is little evidence from research that indicates a connection within a development of profession models and the learning of students. One contributing factor is a lack of reliable data. This shortage of reliable data could be the result of a failure of school leaders to implement a continuous method of evaluating the utilization of strategies presented at staff development activities by the teaching staff (Guskey, 2000). It is indicated that in order to provide high quality professional development, school districts must fund, plan, implement, and evaluate activities that enhance teacher instruction and improve student achievement. Furthermore, Killion (2002) suggested that evaluation is perhaps the most critical component of effective professional development. She stated that evaluation should be comprehensive and ongoing. In addition to the formal evaluation at the end of a professional development activity, school districts should also conduct evaluations during the planning and implementation stages. To build a strong evaluation component, Guskey (2000) suggested that beginning with clear purposes and goals for professional development would make it easier for school district leaders to determine what types of data they would need for evaluation.

Berends and others (2002) believe that the level of program implementation should affect expected student academic outcomes. Empirical evidence has supported this assumption by demonstrating both successful reforms and unsuccessful attempts where the level of implementation fidelity correlated with the outcome (Berends et al., 2002; Berman \& McLaughlin, 1976). In addition, Guskey (2002) suggested that an ongoing, systematic evaluation plan is perhaps the most critical component of planning and sustaining an effective professional development system. He reported that many schools and school systems were not examining how well professional development was working 
because there was not an effective evaluation system in place. He suggested that one reason for this omission was that many administrators considered proper evaluation too costly to undertake. Borman and others (2005) argues that since the passage of the No Child Left Behind Act (NCLB) in 2001, schools at both the primary and secondary levels have turned to a variety of school reform models in an effort to raise the academic achievement of their students. As a result of the widespread need for successful reforms, national policy makers and local administrators look for reform programs that can be applied in multiple contexts and deliver measureable outcomes for stakeholders with a diversity of goals (Borman and others, 2008). On the importance of evaluation of programs Guskey and Sparks (1991) suggested that evaluation results provide valuable tools for monitoring and improving policies and procedures. To link professional development to improved teacher efficacy and indirectly to improved student achievement, school districts need to implement a carefully planned and executed evaluation system (Guskey, Sparks, 1991). Killion (2002) stated that for an evaluation system to be valuable it needs to study the impact of development of profession on instructional practices of educationalists and the effects on student learning(Killion, 2002). Furthermore, the evaluation system should be ongoing and sustained.

\section{Aims of the Study}

The study within hand aims at evaluating the impact of a long-standing diploma programs in academic departments in Majmaah University on a variety of measures of program competence. This study identifies factors needed to promote the successful implementation of diploma programs in the Majmaah University. For this research a case study type data has been collected at 8 different academic diploma programs in the University. It tries to answer some questions on the evaluation of diploma programs. The questionnaire protocol used in this study includes hypothesizes about aspects of diploma programs organization and organizational capacity, barriers and resources, and program outcomes for students, staff, and the local community. The study also evaluates some practices related to staff selection, methods of teaching evaluation, students' evaluation methods, staff evaluation, program evaluation, and administrative supports. These practices were instrumental in moderating contextual factors that might have hindered program implementation.

\section{Methodology}

In this research, the following methodology is chosen:

\subsection{Population of the Study}

The recent study explores the responses and opinions of 110 student (males and females) and 31 staff members (males and females). The staff members are from different ranks: professors (22), associate professors(9) and assistant professors(116). Ages of respondents have been categorized into the following:

- Less than 25 years

- $\quad$ From 26 to 35

- $\quad$ From 36 to 45

- More than 46 years old.

These diploma programs are in 8 different academic disciplines. These disciplines are: Attorney and Law, Specific Education, Networks and Technology, Accounting, Education, Measurement \& Evaluation and Guidance \& Counseling.

\subsection{Stakeholders}

The recent study is conducted by using the descriptive method which is based on collecting, analyzing and organizing data quantitatively and qualitatively on the phenomenon subject to study in order to draw insightful conclusions and findings that provide us with better understanding and perception of it(Obeidat et al 2007). The following stakeholders were selected for the study: 
Table 1. Stakeholders with Examples

\begin{tabular}{|c|c|}
\hline Stakeholder & Examples of the vested interest of each stakeholder \\
\hline Teachers & $\begin{array}{l}\text { Professional satisfaction. } \\
\text { Keeping a job. }\end{array}$ \\
\hline Students & $\begin{array}{l}\text { Learning something perceived to have value. } \\
\text { Getting qualifications that can lead to employment. }\end{array}$ \\
\hline Subject and course coordinators & Ensuring that the students' learning meets some quality assurance standards. \\
\hline Faculty deans & $\begin{array}{l}\text { Capacity to provide for increasing numbers of students. } \\
\text { Meeting professional standards of the discipline area. }\end{array}$ \\
\hline $\begin{array}{l}\text { Members of the university's } \\
\text { chancellery }\end{array}$ & $\begin{array}{l}\text { Links to the university's strategic mission. } \\
\text { Cost-effectiveness, especially in the provision of technology. }\end{array}$ \\
\hline Funding body & Assuring that the product is congruent with the grant application. \\
\hline Employers & A focus on graduate capabilities rather than all the intervening experiences. \\
\hline Professional accrediting bodies & $\begin{array}{l}\text { Standards relating to what skills and knowledge graduates require in particular } \\
\text { professions for the } 21 \text { st century. }\end{array}$ \\
\hline
\end{tabular}

\subsection{Method}

Students and members of staff are the principle components of the education system and surveys of their opinions are one of the most important sources of evidence about quality in higher education. They can provide very useful suggestions for improvement that should be considered in the quality cycle for improvement as applied to individual courses, programs, and institutional planning. Yin (1994) suggested the most appropriate methodology for explaining program implementation is case study. Thus, data for the larger study were collected using an in-depth case study approach. Using methods suggested by Mills and Ragan (2000), data collected over the course of an academic year included a systematic survey that identify of the core components of the diploma program. These components served as the basis for the data collection protocol that was followed throughout this process (Weiss, 1998). Hence, for this study case study method has been choosen. Data was collected over the course of an academic year included a systematic survey questionnaire of the students and members of staff in Majmaah University and a survey of the diploma program itself.

\subsection{Tool of the Study}

The recent study made use of the questionnaire as the major tool for collecting data and information about the population of the study. The questionnaire was designed after formulating the theoretical frame of the study and revising past literature on the topic. The data from this investigation led to the identification of the core components of the diploma program. These components served as the basis for the data collection protocol that was followed throughout this process. Data consisted of a total of 35 structured hypothesis questionnaires investigating the different aspects of 8 diploma programs. These diploma programs are in different disciplines like: Attorney and Law, Specific Education, Networks and Technology, Accounting, Education, Measurement and Evaluation and Guidance and Counseling. The study is conducted within the Riyadh campus of Majmaah University.

The questionnaire measures the effectiveness of the diploma programs. it is divided into 6 main sections each of the first five sections tackles 5 hypothesizes for which the population of the study will respond with only one option out of four options ranging from complete agreement to absolute refusal. These options are:

- Strongly agree

- Agree

- Don't agree

- $\quad$ Strongly don't agree. 
Likewise; the last section of the questionnaire includes 10 hypothesizes for which the respondents to the questionnaire will strongly agree, agree, strongly disagree or disagree.

In this paper the questionnaire discusses the extent to which the diploma programs satisfy the needs of students. It covers the following 5 hypothesizes:

1- The Diploma programs satisfy the scientific interests of students.

2- The topics included in the diploma programs are compatible with student's specialization.

3- The curricula delivered satisfy the student's inclinations.

4- The diploma program satisfies the scientific ambition of students.

5- The diploma programs help improve the students' ability to analyze.

\section{Reliability}

To check the reliability, Cronbach's alpha has been run and it shows the following.

Reliability Statistics

\begin{tabular}{cc}
\hline Cronbach's Alpha & N of Items \\
\hline .766 & 5
\end{tabular}

Results shows that Cronbach's alpha value is high (0.766) which gives clear indication that there is internal consistency among the given items.

\section{Factor Analysis}

Factor Analysis is a data reduction technique. It also helps in structure detection among the variables and further helps in studying the underlying crucial factors that cause the maximum variation. Before we proceed for factor analysis first the researcher tested the eligibility of the data by checking KMO- Bartlett's test which is a measure of sampling adequacy. The KMO value is $0.881>0.5$

Table 2. Factor Analysis

\section{KMO and Bartlett's Test}

\begin{tabular}{llr}
\hline Kaiser-Meyer-Olkin Measure of Sampling Adequacy. & .881 \\
\hline \multirow{3}{*}{ Bartlett's Test of Sphericity } & Approx. Chi-Square & 1621.460 \\
& Df & 300 \\
& Sig. & .000 \\
\hline
\end{tabular}

Bartlett's Test of Sphericity indicates a measure of the multivariate normality of set of variables (Significant value is below 0.05 which indicates that multivariate is normal and is therefore acceptable for factor analysis

\begin{tabular}{|c|c|c|}
\hline S.NO & Factor Name & Factor loading value \\
\hline \multirow[t]{2}{*}{1} & Courses meet the student's desire & 0.787 \\
\hline & Programs provide opportunities for students to meet the scientific interests & 0.777 \\
\hline \multirow[t]{2}{*}{2} & Modern techniques facilitate accommodate students to the topics & 0.758 \\
\hline & $\begin{array}{l}\text { Teachers benefit from the computer to provide references for teaching their } \\
\text { courses }\end{array}$ & 0.712 \\
\hline 3 & Teachers give the research work high portion of the marks. & 0.706 \\
\hline 4 & $\begin{array}{l}\text { Diploma programs provide the local community with qualified Saudis in } \\
\text { various disciplines }\end{array}$ & 0.598 \\
\hline 5 & Teachers use the overhead projector in their teaching & 0.792 \\
\hline
\end{tabular}




\section{Hypothesis Testing}

\section{1- To what extent the diploma programs meet the needs of students}

H0: There is no significant association between designation and their opinions on diploma programs meet the needs of students.

Table 3. Statistical Results of First Hypothesis

\section{Crosstab}

\begin{tabular}{|c|c|c|c|c|c|c|c|}
\hline & \multicolumn{4}{|c|}{ 1- To what extent the diploma programs meet the needs of students } & \multirow[t]{2}{*}{ Total } \\
\hline & & & Strongly disagree & Disagree & Agree & Strongly Agree & \\
\hline \multirow{4}{*}{ JOB } & \multirow[b]{2}{*}{ Student } & Count & 2 & 19 & 59 & 29 & 109 \\
\hline & & $\begin{array}{l}\text { \% within } \\
\text { JOB }\end{array}$ & $1.8 \%$ & $17.4 \%$ & $54.1 \%$ & $26.6 \%$ & $100.0 \%$ \\
\hline & \multirow{3}{*}{ Teacher } & Count & 0 & 5 & 17 & 8 & 30 \\
\hline & & $\begin{array}{l}\text { \% within } \\
\text { JOB }\end{array}$ & $0.0 \%$ & $16.7 \%$ & $56.7 \%$ & $26.7 \%$ & $100.0 \%$ \\
\hline \multirow{2}{*}{\multicolumn{2}{|c|}{ Total }} & Count & 2 & 24 & 76 & 37 & 139 \\
\hline & & $\begin{array}{l}\% \text { within } \\
\text { JOB }\end{array}$ & $1.4 \%$ & $17.3 \%$ & $54.7 \%$ & $26.6 \%$ & $100.0 \%$ \\
\hline
\end{tabular}

\section{Chi-Square Tests}

\begin{tabular}{lccc}
\hline & Value & df & \multicolumn{2}{c}{ Asymp. Sig. (2-sided) } \\
\hline Pearson Chi-Square & $.586^{\mathrm{a}}$ & 3 & .900 \\
Likelihood Ratio & 1.008 & 3 & .799 \\
Linear-by-Linear Association & .096 & 1 & .757 \\
N of Valid Cases & 139 & & \\
\hline
\end{tabular}

a. 2 cells (25.0\%) have expected count less than 5 . The minimum expected count is .43 .

From the table 3, chi square is not significant (sig. value is greater than 0.05 ), no evidence to reject null hypothesis. It means that there is no significant association between designation and their opinions on diploma programs meet the needs of students.

\section{2- To what extent the diploma programs meet the needs of community}

H0: There is no significant association between designation and their opinions on diploma programs meet the needs of community.

Table 4. Statistical Results of Second Hypothesis

\section{Crosstab}

\begin{tabular}{|c|c|c|c|c|c|c|c|}
\hline & \multicolumn{4}{|c|}{ 2- To what extent the diploma programs meet the needs of community } & \multirow[t]{2}{*}{ Total } \\
\hline & & & Strongly disagree & Disagree & Agree & Strongly Agree & \\
\hline \multirow{4}{*}{ JOB } & & Count & 1 & 18 & 63 & 28 & 110 \\
\hline & Student & $\begin{array}{l}\text { \% within } \\
\text { JOB }\end{array}$ & $0.9 \%$ & $16.4 \%$ & $57.3 \%$ & $25.5 \%$ & $100.0 \%$ \\
\hline & & Count & 0 & 4 & 14 & 12 & 30 \\
\hline & Teacher & $\begin{array}{l}\text { \% within } \\
\text { JOB }\end{array}$ & $0.0 \%$ & $13.3 \%$ & $46.7 \%$ & $40.0 \%$ & $100.0 \%$ \\
\hline \multirow{2}{*}{\multicolumn{2}{|c|}{ Total }} & Count & 1 & 22 & 77 & 40 & 140 \\
\hline & & $\begin{array}{l}\text { \% within } \\
\text { JOB }\end{array}$ & $0.7 \%$ & $15.7 \%$ & $55.0 \%$ & $28.6 \%$ & $100.0 \%$ \\
\hline
\end{tabular}




\section{Chi-Square Tests}

\begin{tabular}{lccr}
\hline & Value & df & Asymp. Sig. (2-sided) \\
\hline Pearson Chi-Square & $2.638^{\mathrm{a}}$ & 3 & .451 \\
Likelihood Ratio & 2.734 & 3 & .435 \\
Linear-by-Linear Association & 1.920 & 1 & .166 \\
N of Valid Cases & 140 & & \\
\hline
\end{tabular}

a. 3 cells (37.5\%) have expected count less than 5. The minimum expected count is .21.

From the table 4, chi square is not significant (sig. value is greater than 0.05 ), no evidence to reject null hypothesis. It means that there is no significant association between designation and their opinions on diploma programs meet the needs of community.

\section{3-The efficiency of teaching and learning methods in diploma programs}

H0: There is no significant association between designation and their opinions on efficiency of teaching and learning methods in diploma program.

Table 5. Statistical Results of Third Hypothesis

\section{Crosstab}

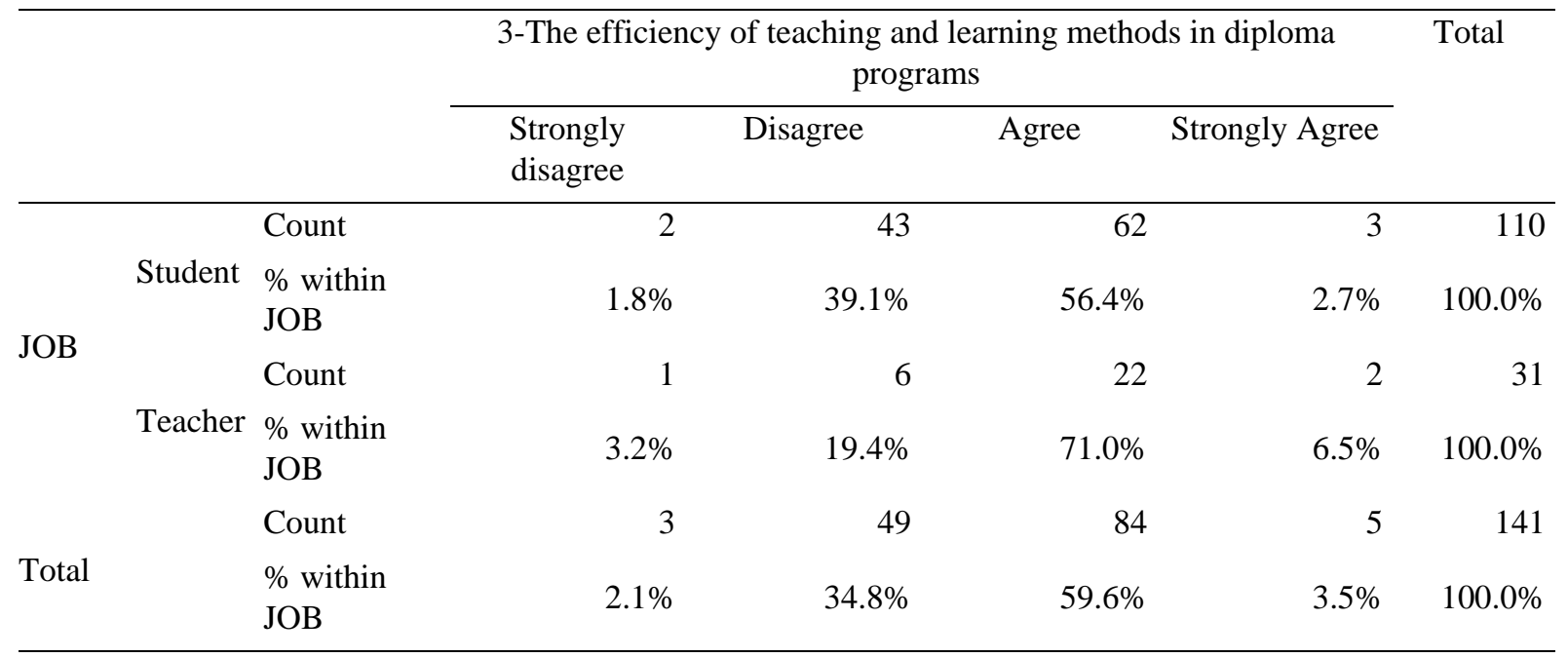

Chi-Square Tests

\begin{tabular}{lccc}
\hline & Value & df & Asymp. Sig. (2-sided) \\
\hline Pearson Chi-Square & $4.748^{\mathrm{a}}$ & 3 & .191 \\
Likelihood Ratio & 4.947 & 3 & .176 \\
Linear-by-Linear Association & 2.990 & 1 & .084 \\
N of Valid Cases & 141 & & \\
\hline
\end{tabular}

a. 4 cells (50.0\%) have expected count less than 5 . The minimum expected count is .66.

From the table 5 chi square is not significant (sig. value is greater than 0.05 ), no evidence to reject null hypothesis. It means that there is no significant association between designation and their opinions on efficiency of teaching and learning methods in diploma program.

\section{4- Using of modern technologies in the diploma programs}

H0: There is no significant association between designation and their opinions on using modern technologies in the diploma programs. 
Table 6. Statistical Results of Fourth Hypothesis

\begin{tabular}{|c|c|c|c|c|c|c|c|}
\hline & & & & sstab & & & \\
\hline & & & 4- Using of $n$ & lern technolo & in the diplc & ma programs & Total \\
\hline & & & $\begin{array}{l}\text { Strongly } \\
\text { disagree }\end{array}$ & Disagree & Agree & Strongly Agree & \\
\hline & Studont & Count & 3 & 24 & 74 & 8 & 109 \\
\hline JOB & student & \% within JOB & $2.8 \%$ & $22.0 \%$ & $67.9 \%$ & $7.3 \%$ & $100.0 \%$ \\
\hline JUB & & Count & 1 & 5 & 22 & 3 & 31 \\
\hline & reacher & \% within JOB & $3.2 \%$ & $16.1 \%$ & $71.0 \%$ & $9.7 \%$ & $100.0 \%$ \\
\hline Total & & Count & 4 & 29 & 96 & 11 & 140 \\
\hline Total & & \% within JOB & $2.9 \%$ & $20.7 \%$ & $68.6 \%$ & $7.9 \%$ & $100.0 \%$ \\
\hline
\end{tabular}

Chi-Square Tests

\begin{tabular}{lccc}
\hline & Value & df & Asymp. Sig. (2-sided) \\
\hline Pearson Chi-Square & $.624^{\mathrm{a}}$ & 3 & .891 \\
Likelihood Ratio & .640 & 3 & .887 \\
Linear-by-Linear Association & .347 & 1 & .556 \\
N of Valid Cases & 140 & &
\end{tabular}

a. 3 cells (37.5\%) have expected count less than 5 . The minimum expected count is .89 .

From the table 6, chi square is not significant (sig. value is greater than 0.05 ), no evidence to reject null hypothesis. It means that there is no significant association between designation and their opinions on using modern technologies in the diploma programs.

\section{5- The efficiency of the methods used to assess students in diploma programs}

H0: There is no significant association between designation and their opinions on efficiency of the methods used to assess students in diploma program.

Table 7. Statistical Results of Fifth Hypothesis

\begin{tabular}{|c|c|c|c|c|c|c|c|}
\hline \multicolumn{8}{|c|}{ Crosstab } \\
\hline & & & \multicolumn{4}{|c|}{$\begin{array}{l}\text { 5- The efficiency of the methods used to assess students in diploma } \\
\text { programs }\end{array}$} & \multirow[t]{2}{*}{ Total } \\
\hline & & & Strongly disagree & Disagree & Agree & Strongly Agree & \\
\hline \multirow{4}{*}{ JOB } & \multirow{3}{*}{ Student } & Count & 2 & 22 & 66 & 20 & 110 \\
\hline & & $\begin{array}{l}\text { \% within } \\
\text { JOB }\end{array}$ & $1.8 \%$ & $20.0 \%$ & $60.0 \%$ & $18.2 \%$ & $100.0 \%$ \\
\hline & & Count & 0 & 2 & 25 & 4 & 31 \\
\hline & \multirow[t]{2}{*}{ Teacher } & $\begin{array}{l}\text { \% within } \\
\text { JOB }\end{array}$ & $0.0 \%$ & $6.5 \%$ & $80.6 \%$ & $12.9 \%$ & $100.0 \%$ \\
\hline \multirow{2}{*}{\multicolumn{2}{|c|}{ Total }} & Count & 2 & 24 & 91 & 24 & 141 \\
\hline & & $\begin{array}{l}\text { \% within } \\
\text { JOB }\end{array}$ & $1.4 \%$ & $17.0 \%$ & $64.5 \%$ & $17.0 \%$ & $100.0 \%$ \\
\hline
\end{tabular}

Chi-Square Tests

\begin{tabular}{lccc}
\hline & Value & $\mathrm{df}$ & Asymp. Sig. (2-sided) \\
\hline Pearson Chi-Square & $5.165^{\mathrm{a}}$ & 3 & .160 \\
Likelihood Ratio & 6.144 & 3 & .105 \\
Linear-by-Linear Association & .859 & 1 & .354 \\
N of Valid Cases & 141 & & \\
\hline
\end{tabular}

a. 2 cells (25.0\%) have expected count less than 5 . The minimum expected count is .44 . 
From the table 7, chi square is not significant (sig. value is greater than 0.05 ), no evidence to reject null hypothesis. It means that there is no significant association between designation and their opinions on efficiency of the methods used to assess students in diploma program.

Table 8. Summary of Hypothesis Testing

\begin{tabular}{lcc}
\hline \multicolumn{1}{c}{ NULL HYPOTHESES } & Sig. value & RESULT \\
\hline $\begin{array}{l}\text { H0: There is no significant association between designation and their opinions on } \\
\text { diploma programs meet the needs of students }\end{array}$ & 0.900 & Accepted \\
$\begin{array}{l}\text { H0: There is no significant association between designation and their opinions on } \\
\text { diploma programs meet the needs of community }\end{array}$ & 0.451 & Accepted \\
$\begin{array}{l}\text { H0: There is no significant association between designation and their opinions on } \\
\text { efficiency of teaching and learning methods in diploma program }\end{array}$ & 0.191 & Accepted \\
$\begin{array}{l}\text { H0: There is no significant association between designation and their opinions on } \\
\text { using modern technologies in the diploma programs }\end{array}$ & 0.891 & Accepted \\
$\begin{array}{l}\text { H0: There is no significant association between designation and their opinions on } \\
\text { efficiency of the methods used to assess students in diploma program }\end{array}$ & 0.160 & Accepted \\
\hline
\end{tabular}

\section{Findings of the Study}

\section{1 - JOB * 1- To what extent the diploma programs meet the needs of students}

H0: There is no significant association between designation and their opinions on diploma programs meet the needs of students

\section{2 - JOB * 2- To what extent the diploma programs meet the needs of community}

H0: There is no significant association between designation and their opinions on diploma programs meet the needs of community

\section{3- JOB * 3-The efficiency of teaching and learning methods in diploma programs}

H0: There is no significant association between designation and their opinions on efficiency of teaching and learning methods in diploma program

\section{4- JOB * 4- Using of modern technologies in the diploma programs}

H0: There is no significant association between designation and their opinions on using modern technologies in the diploma programs

\section{5- JOB * 5- The efficiency of the methods used to assess students in diploma programs}

H0: There is no significant association between designation and their opinions on efficiency of the methods used to assess students in diploma program

\section{Conclusion}

The study shows that from the correlation matrix diploma programs meet the needs of students is positively significant correlated with diploma programs meet the needs of community. The efficiency of teaching and learning methods in diploma programs, using of modern technologies in the diploma programs and efficiency of the methods used to assess students in diploma programs. Further it is highly positively correlate with diploma programs meet the needs of community

The diploma programs meet the needs of community is moderately positively correlated with efficiency of the methods used to assess students in diploma programs. Using of modern technologies in the diploma program is moderately correlated with diploma programs meet the needs of students.

Diploma program effectiveness in this university reflects the overall development of this program in different universities. This university was selected to find out the perception of stakeholders towards these programs so that higher education can take its policies accordingly. As in Saudi Arabia, more and more universities are now launching different diploma programs so that to develop the technical as well as mechanical skills among the students of these universities. Even these programs are now launched on evening hours as well as in summer vacation holidays, for which universities in Saudi Arabia provide necessary facilities for both students as well as to the staff. It is expected 
that in future these course might have lot of scope because of their effectiveness in this country and because of the job market available for them.

\section{References}

Anysia P. (2010). Mayer Factors Influencing the Implementation of an International Baccalaureate Diploma Program in a Diverse Urban High School. Journal of Advanced Academics, 22(1), 78-105. http://dx.doi.org/10.1177/1932202X1002200104

Berends, M., Bodilly, S., \& Kirby, S. (2002). Facing the challenges of whole-school reform: New American Schools after a decade. Santa Monica, CA: RAND Corporation.

Borman, G., Hewes, D., Overman, L., \& Brown, S. (2005). Comprehensive school reform and achievement: A meta-analysis. Review of Educational Research, 29, 125-230.

Cohen, D.K. (1995). What is the system in systematic reform? Educational Researcher, 24(9), 11-17. http://dx.doi.org/10.3102/0013189X024009011

Committee on Standards for Educational Evaluation. (2003). The Student Evaluation Standards: How to Improve Evaluations of Students. Newbury Park, CA: Corwin Press.

Datnow, A., \& Castellano, M. E. (2001). Managing and guiding school reform: Leadership in Success for All schools. Educational Administration Quarterly, 37, 219-249. http://dx.doi.org/10.1177/00131610121969307

Donald B. Yarbrough \& Lyn M. Shulha (2010). The Program Evaluation Standards: A Guide for Evaluators and Evaluation Users. Sage Publications: California.

Ehrmann, S. (1999a). Fix this up. Retrieved from http://www.learner.org/edtech/rscheval/rightquestion.html

Ehrmann, S. (1999b). Flashlight Evaluation Handbook. Flashlight Project. Retrieved December 24, 1999 from http://www.ctl.wsu.edu/CTLSilhouette/mode/author/flashlight/Evaluati onHandbook

Fixsen, D., Naoom, S., Blasé, K., Friedman, F., \& Wallace, F. (2005). Implementation research: A synthesis of the literature (FMHI Publication \#231). Tampa: University of South Florida, Louis de la Parte Florida Mental health Institute, The National Implementation Research Network.

Garet, M. S., Porter, A. C., Desimone, L., Birman, B. F., \& Yoon, K. S. (2001). What makes professional development effective? Results from a national teachers' survey. American Educational Research Journal, 38(4), 915-945. http://dx.doi.org/10.3102/00028312038004915

Guskey, T. R. (2002). Does it make a difference? Evaluating professional development. Educational Leadership, 59(6), 45-51.

Guskey, T. R. (2003). Professional development that Works: What makes professional development effective? Phi Delta Kappan, 84(10), 748-750.

Guskey, T. R., \& Sparks, D. (1991). What to consider when evaluating staff development. Educational Leadership, 49(3), 73-76.

Joint Committee on Standards for Educational Evaluation. (1988). The Personnel Evaluation Standards: How to Assess Systems for Evaluating Educators. Newbury Park, CA: Sage Publications.

Joint Committee on Standards for Educational Evaluation. (1994). The Program Evaluation Standards(2nd Edition). Newbury Park, CA: Sage Publications.

Killion, J. (1999). What works in the middle: Results-based staff development. Oxford, OH: National Staff Development Council. Retrieved December 9, 2006, from http://www.nsdc.org/midbook/index.cfm

Killion, J. (2002). Assessing impact: Evaluating staff development. Thousand Oaks, CA: Corwin Press.

Killion, J. (2011). Assessing impact: Evaluating staff development. Thousand Oaks, CA: Corwin Press.

Louis, K. S., Febey, K., \& Schroeder, R. (2005). State mandated accountability in high schools: Teachers' interpretations of a new era. Educational Evaluation and Policy Analysis, 27, 177-204. http://dx.doi.org/10.3102/01623737027002177

Majmaah (2012). About Majmaah University. Retrieved from http://www.mu.edu.sa/en/search/node/diploma\%20program 
Majmaah University (2013). Western Studies Institute Partners. Retrieved from http://westernstudiesinstitute.org/en/?p=about\&id=1

Manchester. (2013). Interdisciplinary Research. Retrieved from http://www.manchester.ac.uk/abstract/conole.php

Noyce, P. (2012). Professional development: How do we know it works? Education Week, 26(3), 36-37.

Philips R. (2000). Handbook for Learning-centred Evaluation of Computer-facilitated Learning Projects in Higher Education. Retrieved from: http://researchrepository.murdoch.edu.au/12141/1/handbook.pdf

Reeves, T. C. (1999). Evaluation Matrix. Georgia Tech. Retrieved March 29, 1999 from http://mime1.marc.gatech.edu/MM_Tools/EM.html

Rob Phillips et al. (2010). Handbook for learning-centered evaluation of computer-facilitated learning projects in higher education. Release Version 1.0 HTML last modified: April 10, 2000 - 10:30 AM HTML author: Carol Adair, Teaching and Learning Centre Authorised by: Rob Phillips, Educational Designer, Teaching and Learning Centre Copyright $\quad$ (2000) Retrieved from http://www.tlc.murdoch.edu.au/archive/cutsd99/handbook/handbook.html

Rowan, B., \& Correnti, R. (2009). Interventions to improve instruction: How implementation strategies affect instructional change. In W. K. Hoy \& M. DiPaola (Eds.), Studies in school improvement: A volume in research and theory in educational administration.

Weiss, I. R., \& Pasley J. D. (2006). Scaling up instructional improvement through teacher professional development: Insights from the local systemic change initiative. Philadelphia, PA: Consortium for Policy Research in Education. (ERIC Document Reproduction Service No. ED493115)

World News (2012). Joint Committee on Standards for Educational Evaluation 2012. Retrieved from http://wn.com/joint_committee_on_standards_for_educational_evaluation

Zokan, Obeidat et al. (2007). Scientific Research: its definition, Tools and Methods(9 $9^{\text {th }}$ edition). Dar Osama: Amman. 